\title{
Colonic epithelial nodular hyperplasia associated with strongyloidiasis in cats in the Amazon region, Pará State, Brazil
}

\section{Márcio Alan Oliveira Moura ${ }^{1}$ Ediene Moura Jorge ${ }^{2}$ Kelly Karoline Gomes do Nascimento ${ }^{1}$ Gabriela Riet-Correa $^{3}$ Isis Abel $^{3}$ Gustavo Goes Cavalcante ${ }^{3}$ Carlos Alberto de Oliveira $^{3}$ Pedro Soares Bezerra Júnior ${ }^{3^{*}}$}

${ }^{1}$ Faculdade de Medicina Veterinária, Instituto de Medicina Veterinária (IMV), Universidade Federal do Pará (UFPA), Castanhal, PA, Brasil.

${ }^{2}$ Veterinário independente, Castanhal, PA, Brasil.

${ }^{3}$ Programa de Pós-graduação em Saúde Animal na Amazônia (PPGSAAM), Instituto de Medicina Veterinária (IMV), Universidade Federal do Pará (UFPA), Rodovia BR 316, Km 61, Bairro Saudade I, 68743-080, Castanhal, PA, Brasil. E mail: p.s.bezerra.junior@gmail.com. "Corresponding author.

\begin{abstract}
Strongyloides spp. are intestinal parasites that affect several animal species. Four species of the genus have been reported in domestic cats: $\boldsymbol{S}$. felis, $\boldsymbol{S}$. planiceps, $\boldsymbol{S}$.stercoralis and $\boldsymbol{S}$. tumefaciens. Reports describing infection by these nematodes in domestic cats in Brazil are scarce. This study aimed to describe the pathological features of Strongyloides spp. parasitism in two cats in the Amazon region, state of Pará, Brazil. During the necropsy of the two cats, numerous whitish nodules approximately $0.2 \mathrm{~cm}$ in diameter were observed in the wall of the large intestine. The nodules were conspicuous in the colonic mucosa and exhibited a punctate aperture facing the center of the lumen. Microscopically, these nodules were formed by projections of the mucosal epithelium into the submucosa, which formed tubules lined with a single layer of columnar epithelium, with high cellularity and rare goblet cells, characterizing epithelial hyperplasia of the crypts. Adult nematodes and eggs observed in the lumen of the tubules were morphologically compatible with Strongyloides spp. Numerous larvae were also observed in the interstitium adjacent to the nodule. A mild lymphocytic infiltrate was observed neighboring the hyperplastic nodules. The histological changes are consistent with those described for $\boldsymbol{S}$. tumefaciens infection. Key words: Felis catus domesticus, intestinal nematodes, helminth, Strongyloides.
\end{abstract}

Hiperplasia epitelial nodular no cólon de felinos associada à estrongiloidíase na região Amazônica, Pará, Brasil

RESUMO: Strongyloides spp. são helmintos que podem parasitar o intestino de diversas espécies animais. Quatro espécies desse gênero têm sido descritas em felinos domésticos: $\boldsymbol{S}$. felis, $\boldsymbol{S}$. planiceps, $\boldsymbol{S}$. stercoralis $\boldsymbol{e} \boldsymbol{S}$. tumefaciens. Trabalhos sobre o parasitismo por estrongiloides em gatos domésticos no Brasil são escassos. O objetivo deste trabalho é descrever os aspectos patológicos do parasitismo por Strongyloides spp. em dois gatos da região amazônica, no estado do Pará. Estes apresentavam numerosos nódulos esbranquiçados no intestino grosso, medindo cerca de 0,2 centímetros de diâmetro, que na microscopia eram constituídos por projeções do epitélio hiperplásico da mucosa para submucosa, formando túbulos contendo várias fêmeas adultas, ovos e larvas com morfologia compativel com a de Strongyloides spp. e margeados por larvas e remanescentes do aglomerado linfoide. As alterações histológicas foram compativeis com as descritas no parasitismo por $\boldsymbol{S}$. tumefaciens. Palavras-chave: Felis catus domesticus, nematódeos intestinais, helminto, Strongyloides.

Strongyloides spp. are helminths that belong to the Rhabditoidea superfamily and Strongyloididae family and can have both free-living or parasitic reproductive cycles. The parasitic phase is completed by adult parthenogenetic females in the digestive tract of several animal species, including humans. These adult females have a thin, thread-like shape and are a few millimeters long (URQUHART et al., 1991; KASSAI, 1999).

Strongyloidiasis in domestic cats has been associated with $\boldsymbol{S}$. felis, $\boldsymbol{S}$. planiceps, $\boldsymbol{S}$. stercoralis and $\boldsymbol{S}$. tumefaciens. In the three former species, adult female parasitizes the small intestines; however, infection by $\boldsymbol{S}$. tumefaciens is associated with the formation of nodules on the mucosa of the large intestine (PRICE \& DIKMANS, 1941; MALONE et al., 1977; LEVINE et al., 1979; BROWMAN et al., 2002). In Brazil, studies concerning strongyloidiasis in cats are scarce; there are reports of parasitism by $\boldsymbol{S}$. stercoralis in domestic cats (VICENTE et al., 1997) and by an unidentified species of Strongyloides in a wild feline (Leopardus tigrinus) (SANTOS et al., 2009). The present study reports two cases of intestinal strongyloidiasis in cats. Animals were male adult mongrel cats. In the first case, in November 2012, a debilitated stray cat exhibiting muscle weakness and icteric mucous membranes was rescued. The cat died on the way to the clinical care and was submitted 
to necropsy. The main gross lesions included moderately icteric carcass, enhanced lobular pattern of the liver, splenomegaly, lymphadenomegaly and several 0.2 to $2.0 \mathrm{~cm}$ diameter whitish nodules protruding from the colon mucosa and exhibiting a punctate opening facing the intestinal lumen. In the second case, in April 2013, a cat died after chronic diarrhea and progressive weight loss. The only gross lesions reported by the attending veterinarian were whitish nodules on the mucosa of the large intestine, similar to those described in the first case.

Fragments of several organs were collected, fixed in $10 \%$ formalin, processed routinely for histology, sectioned at $5 \mu \mathrm{m}$, stained with hematoxylin and eosin, and observed under optical microscopy.

Histopathology revealed that the large intestine nodules were composed of projections of the mucosal epithelium into the submucosa, which formed tubules lined by a single layer of columnar epithelium with high cellularity (1-2 mitosis / obj. 40) and rare goblet cells (Figure 1A). Lumen of the tubules exhibited transversal sections of nematodes with paired genital tract, uninucleate eggs, and larvae, which were compatible with parasites belonging to the Strongyloididae family. Larvae were also observed in the interstitial tissue between the tubules and the limit of the nodules. Strongyloides spp. were characterized by the presence of rhabditiform eggs, larvae, and adults on cross sections. Eggs measuring 5 to $16 \mu \mathrm{m}$ in diameter were delimited by a thin cuticle. Adult females ranged from 39 to $63 \mu \mathrm{m}$ in diameter. Sometimes it was possible to distinguish structures, such as uterus, ovary, intestine, an external muscle layer and, rarely, the lateral chords, in adults (Figure $1 \mathrm{~A}, \mathrm{~B}$ and $\mathrm{C}$ ). In some cross sections of females, it was possible to recognize eggs in the uterus (Figure 1D) (GARDINER \& POYNTON, 1999). There was a small number of lymphocytes, plasma cells, and macrophages bordering some nodules and interspersed between the tubules. Fragments of the large intestine, which were in formalin and had not been processed for histology, were dissected in an attempt to recover adult parasites; however, only larvae were recovered. These larvae exhibited smooth tegument, rounded head with a short buccal cavity, and a filariform esophagus occupying approximately one third of the body length. The intestinal lumen was straight, and it had a thin tail.

The first cat also exhibited significant lesions in the liver, which were characterized as moderate, focally extensive, necrosuppurative hepatitis with intralesional bacterial colonies. No significant lesions were observed in the few tissues submitted for histology from the second cat.

Histological alterations reported in the large intestine nodules from the cats in this study were identical to those described in parasitism by $\boldsymbol{S}$. tumefaciens (PRICE \& DIKMANS, 1941; MALONE et al., 1977; BOWMAN et al., 2002). Specific parasite identification was not possible in the cases presented here because only formalinfixed samples were available for analysis and only larvae were obtained after dissection of tissues. However, the pattern of tissue response to the parasite observed in the cats of the present study and in the literature on $\boldsymbol{S}$. tumefaciens has not been described in parasitism by other Strongyloides species in domestic cats.

Lesions in the cats of the present study were considered as hyperplasia due the high cellularity and well-differentiated epithelium present in nodules, continuity with the adjacent colonic mucosal crypts, and rarefaction of goblet cells. Few lymphocytes, plasma cells, and macrophages observed, occasionally bordering and interspersed with the hyperplastic nodules, could either be remnants of lymphoid clusters or a reaction to the parasite. Thus, similarly to those described by other authors (MALONE et al., 1977; BARKER et al., 1993; BOWMAN et al., 2002), lesions observed in the cats of this study were interpreted as hyperplasia of the colonic crypt epithelium into the lymphoid clusters. However, some authors characterize this type of lesion as an adenomatous tumor (PRICE \& DIKMANS, 1941).

Microscopic findings are characteristic; however, lymphoid cluster hyperplasia or intestinal lymphoma should be considered when evaluating the gross findings (LINGARD et al., 2009). Other differential diagnoses to be considered are colorectal polyps and intestinal carcinomas (CRIBB, 1988).

Antemortem diagnosis of strongyloidiasis in cats, particularly caused by $\boldsymbol{S}$. tumefaciens, is complex because this parasitism is rarely associated with diarrhea (BARKER et al., 1993). It is unlikely that the lesions observed in the cases were sufficient to cause diarrhea because they were restricted to lymphoid clusters. Diarrhea was reported in only one of the cats. However, it was not possible to establish whether parasitism was the main cause of the diarrhea. In the other cat, death was attributed to liver failure, and parasitism was an incidental finding. It was not possible to determine 


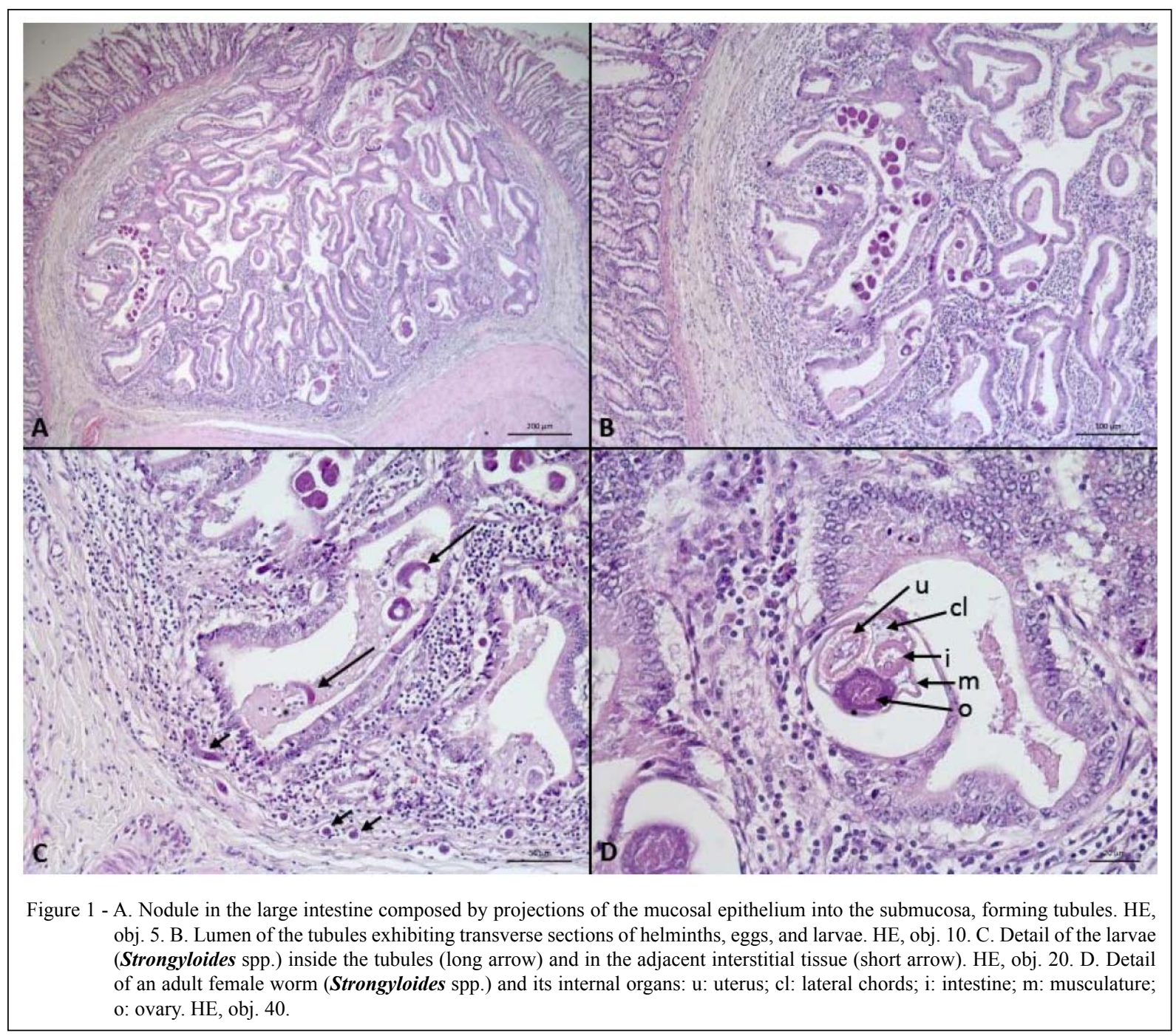

the predisposing factors to parasitism in the cats of this study. Both animals had free access to the streets and had not received proper deworming medication. This access to various environments increased the possibility of contact with infective larvae and the development of parasites. Some limiting factors for the diagnosis of strongyloidiasis are related to the fecal parasitological methods routinely employed. The common stool examination methods require multiple stool samples to achieve higher sensitivity; therefore, the gold standard for the diagnosis of Strongyloides infection is serial stool examination, which is not commonly performed. The Baermann technique after fecal culture is another useful method, but it also not commonly performed in feline medicine (SPEARE \& TINSLEY, 1987). The data presented here indicate that the possibility of infection by this Strongyloides species in cats in Brazil should be investigated.

\section{ACKNOWLEDGEMENTS}

To the Coordenação de Aperfeiçoamento de Pessoal de Nível Superior, Programa Nacional de Pós-doutorado (CAPES-PNDN) for the postdoctoral scholarship granted to the co-author Oliveira C. A.

\section{REFERENCES}

BARKER, I.K. et al. The alimentary system. In: JUBB, K.V.F. et al. Pathology of domestic animals. San Diego, Academic Press, 1993. V.2, cap. 1, p.1-318

BOWMAN, D.D. et al. Feline clinical parasitology. Ames: Iowa State University, 2002. cap.4, p.239-241.

CRIBB, A.E. Feline gastrointestinal adenocarcinoma: A review and retrospective study. Canadian Veterinary 
Journal, v,29, n.9, p.709-712, 1988. Available from: <http://www.ncbi.nlm.nih.gov/pmc/articles/PMC1680855/>. Accessed: Feb. 15, 2016.

GARDINER, C.H.; POYNTON, S.L. An atlas of metazoan parasites in animal tissues. Washington, D.C.: Armed Forces Institute of Pathology, 1999. 64p.

KASSAI, T. Veterinary helminthology. Oxford: ButterworthHeinemann, 1999. 260p.

LEVINE, N.D. Nematode parasites of domestic animals and of man. 2.ed. Minneapolis, Minn.: Burgess Pub. Co., 1979. p.477.

LINGARD, A.E. et al. Low-grade alimentary lynphoma: clinicopathological findings and response to treatment in 17 cases. Journal of Feline Medicine and Surgery, v.11, p.692700, 2009. Available from: <http://www.ncbi.nlm.nih.gov/ pubmed/19576832>. Accessed: Feb. 15, 2016. doi: 10.1016/j. jfms.2009.05.021.

MALONE, J.B. et al. Strongyloides tumefaciens in cats. Journal of American Veterinary Medical Association, v.171, n.3, p.278-280, 1977. Available from: <http://www.ncbi.nlm.nih.gov/ pubmed/893214>. Accessed: Feb. 15, 2016.
PRICE, E.W.; DIKMANS, G. Adenomatous tumors in the large intestine of cats caused by Strongyloides tumefaciens, n. sp. Proceedings of the Helminthological Society of Washington, v.8, p. 41-44, 1941. Available from: <http://science.peru.edu/COPA/ ProcHelmSocWash_V8_N2_1941I.pdf >. Accessed: Feb. 15, 2016.

SANTOS, K.R.; et al. First report of Strongyloides sp. in Leopardus tigrinus in the municipality of Botucatu, State of São Paulo, Brazil. Revista Brasileira de Parasitologia Veterinária, v.18, supl.1, p.7779, 2009. Available from: <http://www.scielo.br/pdf/rbpv/v18s1/ a16v18s1.pdf>. Accessed: Feb. 15, 2016. doi:10.4322/rbpv.018e1016.

SPEARE, R.; TINSLEY, D.J. Survey of cats for Strongyloides felis. Autralian Veterinary Journal. v.64, n.6, p.191192, 1987. Available from: <https://www.researchgate.net/ publication/19528433_Survey_of_cats_for_Strongyloides_felis $>$. Accessed: Feb. 15, $20 \overline{16}$.

URQUHART, G.M. et al. Parasitologia veterinária. Rio de Janeiro: Guanabara Koogan, 1991. 57p.

VICENTE, J.J. et al. Nematóides do Brasil. Parte V: Nematóides de mamíferos. Revista Brasileira de Zoologia, v.14 Supl.1, p.452, 1997. Available from: <http://www.scielo.br/pdf/rbzool/v14s1/ v14s1.pdf>. Accessed: Feb. 15, 2016. 